\title{
POTENTIALLY INAPPROPRIATE MEDICATION USE IN OLDER ADULTS: PREVALENCE AND PHYSICIAN KNOWLEDGE
}

\author{
Medicamentos potencialmente inapropriados para idosos: \\ prevalência de uso e conhecimento médico
}

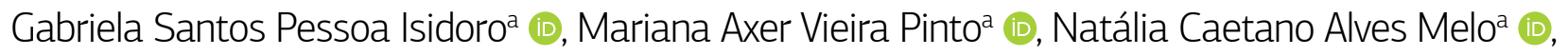

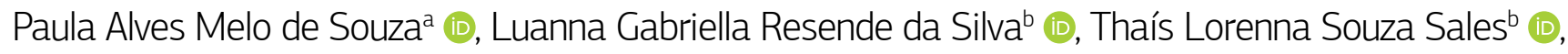

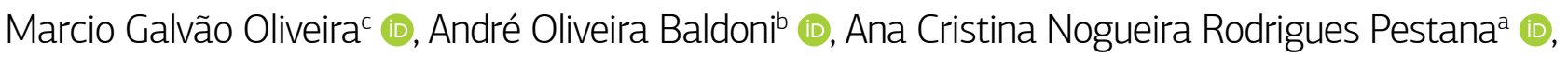 \\ Farah Maria Drumond Chequerb
}

OBJECTIVE: To analyze the frequency, profile, and additional variables associated with the prescription of potentially inappropriate medications (PIM) to older adults in primary care, and evaluate physicians' knowledge about these medications. METHODS: A cross-sectional study was conducted based on data from patient records for the period of January 2014 to December 2017 in a city located in the state of Minas Gerais. The frequency of PIM use was evaluated based on the 2019 Beers-Fick criteria. Physician knowledge was evaluated using a validated questionnaire as a primary data source. RESULTS: In a sample of 423 older adults, $75.89 \%(n=321)$ used at least one PIM, the most common of which were medications used to treat central nervous system disorders $(48.00 \% ; n=203)$. Most participants were female $(62.41 \% ; n=264)$ and 70 years or older $(69.50 \% ; n=294)$. When presented with clinical cases illustrating common situations in the management of older patients, $53.33 \%$ of physicians $(n=8)$ answered four or five questions correctly out of a possible seven; $13.33 \%$ $(n=2)$ answered six questions correctly; and 33.33\% $(n=5)$ obtained three correct answers or fewer. CONCLUSIONS: These findings showed a high frequency of PIM use among older adults treated in Primary Health Care settings, with medications used in the treatment of central nervous system disorders. Our results highlight the importance of continuing education for health professionals and improved assessments of the medication available in the Unified Health System (Sistema Único de Saúde; SUS) for use in older adults, especially those taking multiple medications.

KEYWORDS: older adults; potentially inappropriate medication; Primary Health Care.

aUniversidade de Itaúna - Itaúna (MG), Brazil.

bUniversidade Federal de São João del-Rei - Divinópolis (MG), Brazil.

Instituto Multidisciplinar em Saúde, Universidade Federal da Bahia - Vitória da Conquista (BA), Brazil.

Correspondence data

Farah Maria Drumond Chequer - Universidade Federal de São João del-Rei - Rua Sebastião Gonçalves Coelho, 400 - Chanadour - CEP: 35501 -296 Divinópolis (MG), Brazil. E-mail: farahchequer@ufsj.edu.br

Received on: 12/09/2020. Accepted on: 08/01/2021

How to cite this article: Isidoro GSP, Pinto MAV, Melo NCA, Souza PAM, Silva LGR, Sales TLS, et al. Potentially inappropriate medication use in older adults: prevalence and physician knowledge. Geriatr Gerontol Aging. 2021;15:e0210011. https://doi.org/10.5327/Z2447-212320212000112 https://doi.org/10.5327/Z2447-212320212000112 
OBJETIVOS: Analisar a frequência, o perfil e os fatores associados à prescrição de medicamentos potencialmente inapropriados (MPI) aos idosos na Atenção Primária à Saúde, além de avaliar o conhecimento dos médicos sobre esses medicamentos. METODOLOGIA: Trata-se de um estudo transversal, cujas informações foram coletadas de prontuários dos pacientes, referentes ao período de janeiro de 2014 a dezembro de 2017, em um município localizado no estado de Minas Gerais. Para análise da frequência de uso de MPI, utilizou-se o critério Beers-Fick de 2019. Para avaliação do conhecimento médico, utilizou-se uma fonte primária de informação, um questionário validado. RESULTADOS: Dos 423 idosos, 75,89\% ( $\mathrm{n}=321$ ) utilizavam pelo menos um MPI e a classe mais utilizada foi do sistema nervoso central (48,00\%; n=203). Houve maior prevalência no sexo feminino (62,41\%; $n=264)$ e em idosos com idade $\geq 70$ anos (69,50\%; n=294). Em relação aos casos clínicos apresentados para avaliar o conhecimento dos médicos referentes às situações comuns no cuidado à saúde do idoso, 53,33\% ( $n=8)$ acertaram quatro ou cinco questões das sete existentes, enquanto $13,33 \%(n=2)$ responderam corretamente a seis perguntas e $33,33 \%$ ( $n=5$ ) obtiveram três ou menos acertos. CONCLUSÕES: Os resultados evidenciaram alta taxa de prescrição de MPI entre os idosos da Atenção Primária à Saúde, destacando-se os medicamentos que são destinados ao tratamento de doenças do sistema nervoso central. Ressalta-se a importância da educação continuada desses profissionais de saúde e a melhor avaliação de medicamentos incorporados ao Sistema Único de Saúde (SUS) e destinados à população geriátrica, sobretudo o idoso polimedicado.

PALAVRAS-CHAVE: idoso; lista de medicamentos potencialmente inapropriados; Atenção Primária à Saúde.

\section{INTRODUCTION}

The World Health Organization (WHO) and the Statute of the Elderly define older adults as all those aged 60 years or older based on the fact that Brazil is a developing country. ${ }^{1,2}$ According to the 2019 National Household Sampling Survey (Pesquisa Nacional por Amostra de Domicílios; PNAD), the population of older adults in the country increased by $29.37 \%$ from 2012 to 2019 , reaching a total of 32 million. ${ }^{3,4}$

The accelerated demographic transition and lack of adaptation of the Brazilian health care system have resulted in a deficient infrastructure and unprepared health professionals, ${ }^{5,6}$ so that the aging population faces increasingly severe and complex illnesses with no access to specialized treatment and adequate care. ${ }^{7}$ The challenge of caring for a growing older population must be met with public policy initiatives directed at the Unified Health System (Sistema Único de Saúde; SUS) that encourage greater investment in the training and education of primary care workers, and the development of health promotion, prevention, and treatment interventions. ${ }^{8,9}$

Medications are defined as potentially inappropriate (PIM) for older adults when their risks outweigh their benefits and/or there is evidence to support an alternative treatment strategy that is equally or more effective and carries a lower risk. This classification is performed based on explicit and objective criteria such as those provided by the Brazilian Consensus on Potentially Inappropriate Medication for Older Adults and the Beers-Fick criteria, last updated by the American Geriatrics Society in 2019, which apply to all older adults in outpatient care, including those in long term care institutions, except for individuals receiving palliative care or with a history of severe psychiatric illness. ${ }^{10,11}$

Inadequate prescriptions may lead to several adverse effects, including confusion, gastrointestinal bleeding, falls, fractures, and, consequently, increased mortality rates. ${ }^{12}$ However, many medications can be safely used by older adults - though it must be noted that every individual is unique and clinical decisions should be made on a caseby-case basis. ${ }^{13,14}$

Population-based studies show a high prevalence of PIM use in Brazil, with rates ranging from 34.53 to $53.74 \%$ according to studies based on the 2015 Beers criteria. ${ }^{6,15}$ The use of at least one PIM can double the risk of adverse events, which are responsible for nearly $24.00 \%$ of hospitalizations in older adults. ${ }^{16}$

PIM is frequently prescribed at all levels of health care in Brazil. In the city of Porto Alegre, the prescription rate of PIM was found to be $88.89 \%$ in primary care settings. ${ }^{17}$ In a hospital in the state of Espírito Santo, the prevalence of PIM use was $29.16 \%,{ }^{18}$ and in an outpatient clinic in São Paulo, this figure was $37.61 \% .^{19}$ International studies have also demonstrated a progressive increase in the prescription of PIM, with prescription rates ranging from 42.72 to $52.21 \%$ according to the 2015 Beers criteria. ${ }^{20,21}$

In light of these observations, it is important to identify the PIM most commonly used by older adults and the reasons for their prescription. Therefore, this study aimed to characterize the prescription of PIM for older adults in Primary Care, in addition to investigating the variables associated with the prescription of PIM and the knowledge of primary care physicians regarding the use of these medications. 


\section{METHODS}

Location of study

This study was conducted in the state of Minas Gerais, in a city with an estimated population of 93,214 people. ${ }^{22}$ The city's primary care network comprises 22 Primary Health Care units, including 21 Family Health Strategy (Estratégia Saúde da Familia) teams and one conventional Health Unit. This study included 20 Family Health Strategy teams after the exclusion of two units, one due to its remote location (the Rural Family Health Strategy) and the other for being a basic health care unit and not containing a Family Health Strategy team.

\section{Study design}

This cross-sectional study was conducted in two stages.

\section{Part A: profile and frequency of potentially inappropriate medication}

This stage was based on secondary data collected from the medical records of older adults seen by the Family Health Strategy teams. Information was obtained for the period of January 2014 to December 2017, and a single record was collected per patient. The frequency and use of PIM were evaluated based on the Beers-Fick (2019) criteria which list inappropriate medications regardless of diagnosis. ${ }^{10}$ Subsequently, PIMs were categorized based on the Anatomical Therapeutic Chemical Classification System (ATC). ${ }^{23}$

A total of 11,525 older adults were registered in the city's Family Health Strategy. The sample size was calculated based on a prevalence of $50.00 \%$ given the wide range of estimates in previous studies of PIM; a precision of 5.00\%; a confidence level of $95.00 \%$; and an attrition rate of $20.00 \%$, yielding a final sample of 423 older adults.

Cases were proportionately sampled based on the number of older adults registered in each Health Unit, and medical records were randomly selected by simple random draw using the randomizer tool.

The final sample included the records of 423 patients aged 60 years or older, registered in urban Health Units. Medical records with crossed out, illegible, and/or missing information on main variables (patient identification, medical history, and physical examination) were excluded.

The records were then reviewed by previously trained researchers who used a form to extract relevant information on the population.

\section{Part B: assessment of physician knowledge}

Data for this stage were collected using a questionnaire validated by Almeida ${ }^{24}$ to evaluate physicians' knowledge of PIM. The instrument contains questions regarding the prescriber's clinical practice, the sources of information used to write prescriptions, knowledge, and use of Beers criteria, and personal perception of their prescribing skills for older patients, as well as multiple-choice questions regarding clinical scenarios based on 2012 Beers criteria. ${ }^{24}$

Seven clinical cases that represent common situations in older patient care were presented to physicians to evaluate their knowledge of Beers criteria. Physicians were given 5 options from which to choose the most appropriate medications for each case, and the ones to be avoided. The first question addressed the physicians' confidence in their ability to prescribe medication for older adults. Questions 2 and 3 addressed the sources consulted by physicians when prescribing for older adults. Three questions $(4,5$, and 10) address the treatment of hypertension and arrhythmia; another three (6, 7, and 8 ) addressed depression, anxiety, and insomnia; and one question (9) discussed treatment options for arthritis pain management.

This study involved all 20 physicians employed in the Family Health Strategies included in the study from January 2018 to July 2019. However, there was a sample loss of five participants, as shown in Figure 1. The questionnaires were administered in the presence of at least one member of the research team. Physicians were asked to complete the instrument with no reference to external sources, in a maximum of 10 minutes.

\section{Data Analysis}

Data from the medical records and physician questionnaires were collected using standardized instruments, then entered into the Questionnaire Development System ${ }^{\oplus}$ (version 2.6.1) (QDS) and exported to the Statistical Package for the Social Sciences - SPSS (version 19.0). Results were expressed as frequencies and percentages, medians, interquartile ranges, means, and standard deviations. The normality of continuous data was analyzed using Kolmogorov-Smirnov tests. The $\chi^{2}$ test was used to verify whether there were differences in age and gender between patients who used PIM and those who did not. Differences were considered statistically significant when $\mathrm{p}<0.05$.

\section{Ethical concerns}

This study was approved by the Research Ethics Committee for human research (CAAE: 90044518.1.0000.5144) and authorized by the city's Municipal Health Department. 


\section{RESULTS}

A total of $62.41 \%(n=264)$ of the 423 participants in the study were female and $69.50 \%(n=294)$ were 70 years or older (Table 1). Questions regarding the use of PIM revealed that $75.89 \%(n=321)$ of participants used at least one of these medications (Table 2), the most common of which were those targeting the central nervous system (CNS), with a prevalence of $47.99 \%(n=203)$, followed by drugs

Potentially inappropriate medication use in older adults: prevalence and physician knowledge

Prevalence of potentially inappropriate medication use and associated

factors in oldler adults

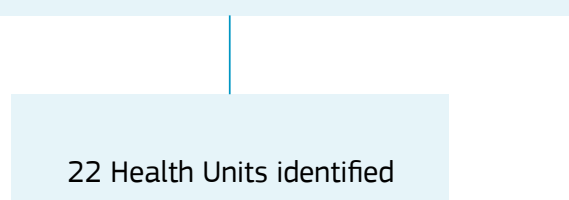
Health Unit:

not a Family Health

Strategy (Estratégia Saúde da Família;

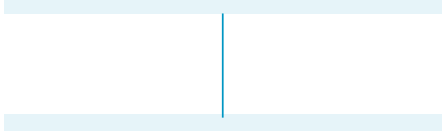

Exclusion of Rural Family Health Strategy: difficult accessibility

Total: 20 participating Family Health Strategy teams
Physician knowledge of potentially inappropriate medication for older adults

22 physicians identified

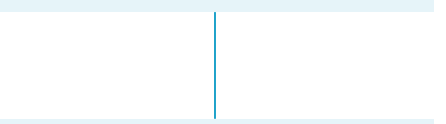

Exclusion of physicians from the Central Health Unit and Rural Family Health Strategy

5 losses*

Total: 15 participating

*Losses: one physician on maternity leave; one physician who temporarily worked at two different units; and three refusals to answer the questionnaire. Figure 1. Flow diagram of exclusion of Health Units and sample loss among primary care physicians in a city in the state of Minas Gerais. 
affecting the digestive, metabolic, and musculoskeletal systems, as shown in Table 3.

Two of the 20 physicians were on holiday or maternity leave, while three refused to participate in the study, which resulted in a final sample of 15 physicians. These participants had a mean of $7.73(\mathrm{SD}, 4.65)$ years of experience and were predominantly general practitioners $(46.67 \%, n=7)$.

Sixty percent of physicians $(n=9)$ informed that at least $50.00 \%$ of their patients were older adults. Furthermore, $86.67 \%(\mathrm{n}=13)$ were confident in their ability to prescribe medication for this population. Forty percent $(n=6)$ rarely consulted the Beers criteria when writing prescriptions and $26.67 \%(n=4)$ were aware of these criteria but never used them. A further $13.33 \%(n=2)$ of participants had never heard of the Beers criteria.

When presented with the clinical cases illustrating common situations in the management of older patients, 53.33\% of physicians $(\mathrm{n}=8)$ answered four or five questions correctly out of a possible seven; $13.33 \%(n=2)$ answered six questions correctly; and 33.33\% ( $\mathrm{n}=5)$ obtained three correct answers or fewer. The clinical cases with the lowest accuracy rates involved the treatment of recurring atrial fibrillation, with an accuracy of $20.00 \%(n=3)$, and long-term management of arthritis pain, with an accuracy of $26.67 \%(n=4)$, as shown in Table 4.

For $93.33 \%(n=14)$ of physicians, the main barrier to prescribing adequate medication for older adults was the limited number of medications available in the SUS. Other factors associated with the prescription of PIM were: patient unwillingness to stop taking medication prescribed by other physicians $(86.67 \%, \mathrm{n}=13)$; medication costs to the patient $(86.67 \%, \mathrm{n}=13)$; lack of information on medications already used by the patient $(66.67 \%, \mathrm{n}=10)$; difficulty communicating with the other physicians treating the patient $(66.67 \%, \mathrm{n}=10)$; and the large number of medications taken by the patient $(60.00 \%, \mathrm{n}=9)$.

\section{DISCUSSION}

This study found a prevalence of $75.89 \%$ for the use of PIM in older adults treated in the SUS. This figure is higher than that observed in countries such as India $(16.00 \%),{ }^{25}$ Nigeria (25.45\%), ${ }^{26}$ Ireland (28.00\%), ${ }^{27}$ New Zealand (42.72\%), ${ }^{20}$ and Indonesia (52.21\%). ${ }^{21}$

However, the increasing prevalence of the use of these medications is supported by previous studies involving older adults in Brazil, where over half of the samples use at least one PIM. A cohort study performed by Nascimento et al. ${ }^{9}$ in a city in Minas Gerais found that $56.00 \%$ of a sample of 1,371 older adults used PIMs. A cross-sectional retrospective study of 202 adults aged $\geq 65$ years in a city in Santa Catarina found that the prevalence of PIM use was $55.45 \% .^{28}$ In a

Table 2. Number of potentially inappropriate medications used by older adults treated in the Primary Care Network of a city in the state of Minas Gerais.

\begin{tabular}{l|c|c}
$\begin{array}{l}\text { Number of potentially } \\
\text { inappropriate } \\
\text { medications used by } \\
\text { older adults }\end{array}$ & $\mathrm{n}$ \\
\hline None & 102 & 24.10 \\
\hline 1 & 121 & 28.60 \\
\hline 2 to 3 & 151 & 35.70 \\
\hline$\geq 4$ & 49 & 11.60 \\
\hline Total & 423 & 100 \\
\hline
\end{tabular}

Table 1. Distribution of older adults treated in primary care by age group, gender, and use of potentially inappropriate medication $(n=423)$.

\begin{tabular}{|c|c|c|c|c|c|c|c|}
\hline \multirow{3}{*}{ Variables } & \multirow{2}{*}{\multicolumn{2}{|c|}{ Total }} & \multicolumn{4}{|c|}{ Use of potentially inappropriate medication } & \multirow{3}{*}{ p-value* } \\
\hline & & & & & & & \\
\hline & $\mathrm{n}$ & $\%$ & $\mathrm{n}$ & $\%$ & $\mathrm{n}$ & $\%$ & \\
\hline \multicolumn{8}{|l|}{ Age (years) } \\
\hline 60 to 64 & 26 & 6.14 & 9 & 8.82 & 17 & 5.29 & \multirow{3}{*}{0.41} \\
\hline 65 to 69 & 103 & 24.34 & 23 & 22.54 & 80 & 24.92 & \\
\hline$\geq 70$ & 294 & 69.50 & 70 & 68.62 & 224 & 69.78 & \\
\hline \multicolumn{8}{|l|}{ Sex } \\
\hline Male & 159 & 37.58 & 53 & 51.96 & 106 & 33.02 & \multirow{2}{*}{$0.001^{*}$} \\
\hline Female & 264 & 62.41 & 49 & 48.03 & 215 & 66.97 & \\
\hline
\end{tabular}

${ }^{*} \mathrm{p}<0.05$. Statistic: $\chi^{2}$. 
Table 3. Most frequently used inappropriate medications in older adults according to the Beers (2019) criteria and the Anatomical Therapeutic Chemical Classification System $(n=423)$.

\begin{tabular}{|c|c|c|}
\hline $\begin{array}{l}\text { Anatomical Therapeutic Chemical } \\
\text { Classification System }\end{array}$ & $\mathbf{n}$ & $\%$ \\
\hline Central nervous system & 203 & 47.99 \\
\hline Clonazepam & 83 & 19.62 \\
\hline Amitriptyline & 53 & 12.53 \\
\hline Alprazolam & 43 & 10.16 \\
\hline Diazepam & 37 & 8.74 \\
\hline Zolpidem & 28 & 6.62 \\
\hline Paroxetine & 19 & 4.49 \\
\hline Phenobarbital & 15 & 3.54 \\
\hline Risperidone & 12 & 2.83 \\
\hline Quetiapine & 9 & 2.12 \\
\hline Lorazepam & 8 & 1.89 \\
\hline Nortriptyline & 6 & 1.41 \\
\hline Imipramine & 5 & 1.18 \\
\hline Clomipramine & 3 & 0.71 \\
\hline Haloperidol & 3 & 0.71 \\
\hline Doxepin & 2 & 0.47 \\
\hline Chlordiazepoxide & 1 & 0.23 \\
\hline Clozapine & 1 & 0.23 \\
\hline Meperidine & 1 & 0.23 \\
\hline Olanzapine & 1 & 0.23 \\
\hline Alimentary tract and metabolism & 124 & 29.31 \\
\hline Omeprazole & 105 & 24.82 \\
\hline Scopolamine & 16 & 3.78 \\
\hline Pantoprazole & 8 & 1.89 \\
\hline Esomeprazole & 1 & 0.23 \\
\hline Hyoscyamine & 2 & 0.47 \\
\hline Dicyclomine & 1 & 0.23 \\
\hline Lanzoprazole & 1 & 0.23 \\
\hline Musculoskeletal system & 102 & 24.11 \\
\hline Ibuprofen & 70 & 16.54 \\
\hline Meloxicam & 22 & 5.20 \\
\hline Cyclobenzaprine & 16 & 3.78 \\
\hline Acetylsalicilic acid & 10 & 2.36 \\
\hline Carisoprodol & 5 & 1.18 \\
\hline Ketoprofen & 5 & 1.18 \\
\hline Naproxen & 5 & 1.18 \\
\hline Ketorolac tromethamine & 4 & 0.94 \\
\hline Etodolac & 2 & 0.47 \\
\hline Indometacine & 1 & 0.23 \\
\hline Piroxicam & 1 & 0.23 \\
\hline Respiratory system & 30 & 7.09 \\
\hline Dexchlorpheniramine & 16 & 3.78 \\
\hline Dimenhydrinate & 5 & 1.18 \\
\hline Hydroxyzine & 5 & 1.18 \\
\hline Brompheniramine & 2 & 0.47 \\
\hline Promethazine & 2 & 0.47 \\
\hline Meclizine & 1 & 0.23 \\
\hline Cardiovascular system & 28 & 6.61 \\
\hline Digoxin & 10 & 2.36 \\
\hline Amiodarone & 8 & 1.89 \\
\hline Methyldopa & 7 & 1.65 \\
\hline Clonidine & 3 & 0.71 \\
\hline Doxazosin & 2 & 0.47 \\
\hline Antiinfectives for systemic use & 19 & 4.49 \\
\hline Nitrofurantoin & 19 & 4.49 \\
\hline
\end{tabular}

cross-sectional, retrospective analytical study of 79 women aged 60 to 68 years in a city in Rio Grande do Sul, this figure was found to be $55.69 \% .^{29}$ Lastly, a cross-sectional observational study of 1000 adults aged $\geq 60$ years in a city in São Paulo found that the prevalence of PIM use was 59.20\%. ${ }^{30}$

Though there has been significant variability between studies, some investigations have noted that the prevalence of PIM use is higher in women ${ }^{28,30}$ and increases with advancing age, especially in individuals older than 70 years..$^{20,28}$ These observations were in line with the present findings.

The aging process is associated with functional impairments in several physiological systems, especially the CNS, the gastrointestinal tract, the kidneys, and the musculoskeletal system, ${ }^{14}$ which may be why the most frequently used inappropriate medications were associated with diseases in these organ systems. Frequent use of CNS medications considered inappropriate for older adults was also observed in the state of Alagoas, where $46.27 \%$ of older adults hospitalized in the Santa Casa de Maceió used inappropriate antipsychotics, while a separate study found that $28.72 \%$ of older adults hospitalized at the Santa Casa de São Paulo received inappropriate medication for gastrointestinal disorders. ${ }^{31,32}$ Both observations reflect the findings of the present study.

Some medications were especially frequent in the sample, such as clonazepam and amitriptyline. In line with the present findings, these drugs were also the most prevalent in a primary care unit in Porto Alegre ${ }^{17}$ (10.32\% clonazepam and $24.60 \%$ amitriptyline) and a long term care facility in São Paulo. ${ }^{32}$ Medication that affects the CNS is especially likely to have altered pharmacokinetic parameters in older adults, as these drugs are highly fat-soluble and older patients have less muscle mass relative to fatty tissue. ${ }^{33}$ Therefore, intoxication and side effects are more frequent in individuals aged 60 years or older, and the most common adverse effects - dizziness followed by falls and fractures- can result in death. ${ }^{14}$

Physicians had high levels of confidence in their ability to prescribe medication for older adults but showed little knowledge of the Beers criteria. These findings are not exclusive to Brazil. In Italy, a cross-sectional study of 155 primary care physicians revealed that $88.00 \%$ of these individuals were confident in their ability to prescribe medication to older patients, but $69.00 \%$ were not aware of the Beers criteria and only $16 \%$ occasionally used this tool. ${ }^{34}$

One hypothesis for the low frequency with which physicians relied on external sources when prescribing medication could be a lack of awareness regarding PIM and their consequences. ${ }^{29}$ Although physicians correctly identified the 
inappropriate medications in multiple-choice questions, the frequency with which PIM are prescribed in the context of Family Health Strategies remains high. Another hypothesis is that PIM classification systems such as the Beers-Fick do not provide alternatives to the medication identified as inappropriate, which makes it difficult to implement these systems in routine clinical practice. ${ }^{35}$

A study performed in the United States analyzed the main barriers to appropriate prescription for older adults and obtained similar findings to those of the present investigation. The difficulties most frequently cited by physicians ( $>50.00 \%$ ), both in Ramaswamy et al. ${ }^{36}$ and the present study, were, respectively: the large number of medications used by the patient ( 91.00 and $66.67 \%$ ); medication costs to the patient (89.00 and $86.67 \%$ ); limited number of medications reimbursed by the SUS or health insurance plans (85.00 and 93.33\%); difficulty communicating with the other physicians treating the patient (61.00 and 66.67\%); lack of information on the medications the patient is already taking (60.00 and $66.67 \%)$; and lack of formal education on prescribing for older adults (54.00 and 60.00\%). Patient unwillingness to stop taking medication prescribed by other physicians was a common issue in the present study (87.67\%) but was not cited by professionals in the United States.

Limitations of the present study include the use of medical records and possible data collection bias due to incomplete or inaccurate information; ${ }^{36}$ the lack of chronological data in the medical records, especially with regard to the discontinuation or initiation of continuous medication; and the lack of data on comorbidities or the justification for the prescription of different drugs. The number of physicians interviewed about their knowledge of PIM was also relatively small.

Possible interventions based on the results of the present study include the encouragement of continuing education programs in primary care, which can contribute to professional development and improved service quality. Furthermore, the implementation of prescription protocols for older adults based on classification criteria for PIM adapted to Brazilian settings would facilitate decision-making by prescribers. ${ }^{35}$ Another crucial measure to reduce the use of PIM is the adjustment of the Municipal List of Essential Medicines (Relação Municipal de Medicamentos Essenciais; REMUME) to provide safe and effective pharmacotherapy alternatives for older adults. ${ }^{29}$

\section{CONCLUSION}

The present findings showed a high frequency of PIM use among older adults treated in Primary Health Care settings, with medications used in the treatment of CNS disorders such as anxiety and depression being especially frequent. The next most frequently used medications were those prescribed for digestive and metabolic diseases. Medication availability in the SUS, patient unwillingness to stop taking medication

Table 4. Accuracy of primary care physicians on multiple-choice questions from the questionnaire validated by Almeida. ${ }^{24}$ Questions Accuracy $(\%)$

A 77-year-old patient with a history of hypertension is taking hydrochlorothiazide, metoprolol, lisinopril, and doxazosin. Their blood pressure is controlled and you would like to discontinue one of these medications. 60.00 The patient has no other medical conditions. Which medication would you discontinue first?

An 85-year-old patient has a history of recurrent atrial fibrillation. Which medication would you avoid, since its prescription is rarely recommended?

20.00

You would like to initiate pharmacological treatment for depression in a 68-year-old patient. They have no other medical conditions. Which medication would you avoid due to its significant anticholinergic effects?

An 82-year-old patient is beginning physical rehabilitation after hospitalization. The patient is very anxious and may not benefit from physical therapy if they do not receive medication to control their anxiety. The patient has no history of loss of consciousness or falls. You decide to initiate low-dose benzodiazepine treatment. Which medication would be most appropriate for this situation?

A 70-year-old patient is having trouble sleeping. Your recommendations regarding sleep maintenance and rest have not had positive results. You decide to prescribe a short-term pharmacological treatment. The patient has no other medical conditions. Which medication would be your first choice?

A 75-year-old patient has arthritis pain and you decide to initiate a long-term treatment to help them manage these symptoms. Which medication would be your first choice?

80.00

Despite taking several medications, your 86-year-old patient has uncontrolled hypertension. The patient has a history of cerebrovascular accidents and progressive dementia. You decide to alter their prescribed therapy. Which medication should you avoid due to its adverse effects on the central nervous system? 
prescribed by other physicians, and the cost of medication to the patients were all linked to the prescription of PIM.

Although physicians performed well on the questionnaires used in this study, a significant number of these individuals did not rely on the Beers-Fick criteria when prescribing medications, which highlights the importance of continuing education for these professionals and improved assessment of medications available in the SUS for the treatment of older adults.

\section{ACKNOWLEDGEMENTS}

The authors thank the Universidade de Itaúna and the Universidade Federal de São João del-Rei for their help and support. This study was financed in part by the Coordenação de Aperfeiçoamento de Pessoal de Nível Superior - Brasil (CAPES) - Finance Code 001.

\section{CONFLICTS OF INTEREST}

The authors declare no conflicts of interest.

\section{FUNDING}

This study was financed in part by the Coordenação de Aperfeiçoamento de Pessoal de Nível Superior - Brasil (CAPES) - Finance Code 001.

\section{AUTHOR CONTRIBUTIONS}

GSPI: conceptualization, data curation, formal analysis, writing - original draft. MAVP: conceptualization, data curation, formal analysis, writing — original draft. NCAM: conceptualization, data curation, formal analysis, writing original draft. PAMS: conceptualization, data curation, formal analysis, writing — original draft. LGRS: conceptualization, data curation, formal analysis, writing - original draft. TLSS: formal analysis, methodology, supervision. MGO: validation, writing - review and editing. AOB: conceptualization, methodology, visualization, writing - review and editing. ACNRP: project administration, visualization, writing - review and editing. FMDC: conceptualization, methodology, project administration, visualization, writing - review and editing.

\section{REFERENCES}

1. Organização Mundial da Saúde. Relatório mundial de envelhecimento e saúde. Available from: https://sbgg.org.br/wp-content/ uploads/2015/10/OMS-ENVELHECIMENTO-2015-port.pdf. Accessed in Mar 25, 2020.

2. Brasil. Estatuto do idoso. Available from: https://www2.senado.leg. br/bdsf/bitstream/handle/id/530232/estatuto_do_idoso_1ed.pdf. Accessed in Aug 24, 2020.

3. Instituto Brasileiro de Geografia e Estatística. Pesquisa Nacional por Amostra de Domicílio Contínua: Características gerais dos moradores 2012-2016. Available from: https://biblioteca.ibge.gov. br/visualizacao/livros/liv101377_informativo.pdf. Accessed in Jun 18,2020

4. Instituto Brasileiro de Geografia e Estatística. Pesquisa Nacional por Amostra de Domicílio Contínua: Características gerais dos domicílios e dos moradores 2019. Available from: https://biblioteca. ibge.gov.br/visualizacao/livros/liv101707_informativo.pdf. Accessed in Jun 18, 2020.

5. Miranda GMD, Mendes ACG, Silva ALA. O envelhecimento populacional brasileiro: desafios e consequências sociais atuais e futuras. Rev Bras Geriatr Gerontol [Internet] 2016 [Accessed in 2019 Jun 10];19(3). Available in: https://www.redalyc.org/pdf/4038/403846785012.pdf. https://doi.org/10.1590/1809-98232016019.150140

6. Almeida TA, Reis EA, Pinto IVL, Ceccato MGB, Silveira MR, Lima MG, et al. Factors associated with the use of potentially inappropriate medications by older adults in primary health care: An analysis comparing AGS Beers, EU(7)-PIM List, and Brazilian Consensus PIM criteria. Res Social Adm Pharm [Internet] 2019 [Accessed in 2020 Aug 24]; 15(4). Available in: https://doi.org/10.1016/j. sapharm.2018.06.002

7. United Nations. World Population Ageing 2013. Available from: https://www.un.org/en/development/desa/population/publications/ pdf/ageing/WorldPopulationAgeing2013.pdf. Accessed in Jun 18, 2020.
8. Brito MCC, Freitas CASL, Mesquita KO, Lima GK. Envelhecimento Populacional e os Desafios para a Saúde Pública: Análise da Producão Científica. Kairós [Internet] 2013 [Accessed in 2020 Aug 24]; 16(2). Available in: https://doi.org/10.23925/2176-901X.2013v16i2p161-178

9. Nascimento MMG, Mambrini JVM, Lima-Costa MF, Firmo JOA, Peixoto SWV, Loyola Filho Al. Potentially inappropriate medications: predictor for mortality in a cohort of community-dwelling older adults. Eur J Clin Pharmacol [Internet] 2017 [Accessed in 2020 Aug 24];73(5). Available in: https://doi.org/10.1007/s00228-017-2202-x

10. American Geriatrics Society. Beers Criteria Update Expert Panel. American Geriatrics Society 2019 Updated AGS Beers Criteria for Potentially Inappropriate Medication Use in Older Adults. J Am Geriatr Soc [Internet] 2019 [Accessed in 2020 Aug 24];67(4). Available in: https://doi.org/10.1111/jgs.15767

11. Oliveira MG, Amorim WW, Oliveira CRB, Coqueiro HL, Gusmão LC, Passos LC. Brazilian consensus of potentially inappropriate medication for elderly people. Geriatr Gerontol Aging. 2016;10(4):168-81. https:// doi.org/10.5327/Z2447-211520161600054

12. Castro-Rodríguez A, Machado-Duque ME, Medina-Morales DA, Machado-Alba JE. Identification of potentially inappropriate cardiovascular prescriptions in the elderly using Beers' criteria. Rev Colomb Cardiol [Internet] 2020 [Accessed in 2020 Aug 24];27(2). Available in: https://doi.org/10.1016/j.rccar.2019.02.008

13. Pereira KG, Peres MA, lop D, Boing AAC, Boing AF, Aziz M, et al. Polifarmácia em idosos: um estudo de base populacional. Rev Bras Epidemiol [Internet] 2017 [Accessed in 2020 Jun 2];20(2). Available in: https://doi.org/10.1590/1980-5497201700020013

14. Marques GFM, Rezende DMRP, Silva IP, Souza PC, Barborsa SRM, Penha RM, et al. Polifarmácia e medicamentos potencialmente inapropriados para idosos na enfermagem gerontológica. Rev Bras Enferm [Internet] 2018 [Accessed in 2019 Jun 23];71(5). Available in: http://www.revenf.bvs.br/pdf/reben/v71n5/pt_0034-7167reben-71-05-2440.pdf 
15. Oliveira MG, Amorim WW, Jesus SR, Rodrigues VA, Passos LC. Factors associated with potentially inappropriate medication use by the older adults in the Brazilian primary care setting. Int J Clin Pharm [Internet] 2012 [Accessed in 2019 Nov 07];34(4). Available in: https://link.springer.com/article/10.1007/s11096-012-9656-9. https://doi.org/10.1007/s1 1096-012-9656-9

16. Silvestre SD, Goulart FC, Marin MJS, Lazarini CA. Prescrição de medicamentos potencialmente inapropriados para idosos: comparação entre prestadores de serviços em saúde. Rev Bras Geriatr Gerontol [Internet] 2019 [Accessed in 2020 Jun 10];22(2). Available in: https:// www.scielo.br/pdf/rbgg/v22n2/pt_1809-9823-rbgg-22-02-e180184. pdf. https://doi.org/10.1590/1981-22562019022.180184

17. Bueno D, Almeida TT, Rocha BS. Prevalência de prescrição de medicamentos potencialmente inapropriados para idosos em uma unidade de saúde da família em Porto Alegre-RS. Rev APS [Internet] 2016 [Accessed in 2020 Aug 24]; 19(3). Available in: https://periodicos. uff.br/index.php/aps/article/view/15579

18. Nassur BA, Braun V, Devens LT, Morelato RL. Avaliação dos medicamentos inapropriados utilizados por idosos admitidos em hospital geral filantrópico. Rev Bras Clin Med [Internet] 2010 [Accessed in 2020 Jan 18];8(3). Available in: http://files.bvs.br/ upload/S/1679-1010/2010/v8n3/a005.pdf

19. Faustino CG, Martins MA, Jacob Filho W. Medicamentos potencialmente inapropriados prescritos a pacientes idosos ambulatoriais de clínica médica. Einstein (São Paulo) [Internet] 2011 [Accessed in 2020 Aug 24];9(1). Available in: https://doi.org/10.1590/s1679-45082011ao1844

20. Nishtala PS, Bagge ML, Campbell AJ, Tordoff JM. Potentially inappropriate medicines in a cohort of community-dwelling older people in New Zealand. Geriatr Gerontol Int. 2014;14(1):89-93. https://doi.org/10.1111/ggi.12059

21. Abdulah R, Insani WN, Destiani DP, Rohmaniasari N, Mohenathas ND, Barliana MI. Polypharmacy leads to increased prevalence of potentially inappropriate medication in the Indonesian geriatric population visiting primary care facilities. Ther Clin Risk Manag. 2018;2018:1591-7. https://doi.org/10.2147/TCRM.S170475

22. Instituto Brasileiro de Geografia e Estatística. Diretoria de Pesquisas. Coordenação de População e Indicadores Sociais. Estimativas da população residente com data de referência $1^{\circ}$ de julho de 2019. Available from: https://www.ibge.gov.br/cidades-e-estados/mg/ itauna.html. Accessed in Aug 28, 2020.

23. World Health Organization. The Anatomical Therapeutic Chemical. Classification System with Defined Daily Doses (ATC/DDD). Available from: https://www.who.int/standards/classifications/otherclassifications/the-anatomical-therapeutic-chemical-classificationsystem-with-defined-daily-doses/. Accessed in Mar 25, 2020.

24. Almeida NS. Validação de instrumento para avaliar a compreensão de médicos que trabalham com idosos, a respeito dos medicamentos potencialmente inapropriados para população [trabalho de Conclusão de Curso]. Bahia: Instituto Multidisciplinar em Saúde da Universidade Federal da Bahia; 2014.

25. Undela K, Bansal D, D'Cruz S, Sachdev A, Tiwari P. Prevalence and determinants of use of potentially inappropriate medications in elderly inpatients: a prospective study in a tertiary healthcare setting. Geriatr Gerontol Int. 2014:14(2):251-8. https://doi.org/10.1111/ggi.12081
26. Fadare JO, Agboola SM, Opeke OA, Alabi RA. Prescription pattern and prevalence of potentially inappropriate medications among elderly patients in a Nigerian rural tertiary hospital. Ther Clin Risk Manag. 2013;2013:115-20. https://doi.org/10.2147/TCRM. S40120

27. Cahir C, Moriarty F, Teljeur C, Fahey T, Bennett K. Potentially inappropriate prescribing and vulnerability and hospitalization in older community-dwelling patients. Ann Pharmacother. 2014;48(12):154654. https://doi.org/10.1177/1060028014552821

28. Massarolo REP. Prescrições potencialmente inapropriadas com ação no sistema nervoso central: prevalência de uso em pacientes de um município de pequeno porte do estado de Santa Catarina [dissertação]. Florianópolis: Universidade Federal de Santa Catarina; 2017.

29. Bandeira VAC, Gewehr DM, Colet CF, Oliveira KR. Identificação do uso e fatores associados ao consumo de medicamentos potencialmente inapropriados por idosas. Estud Interdiscipl Envelhec [Internet] 2018 [Accessed in 2020 Aug 24];23(3). Available in: https://www.seer. ufrgs.br/RevEnvelhecer/article/viewFile/64613/52833. https://doi. org/10.22456/2316-2171.64613

30. Baldoni AO, Ayres LR, Martinez EZ, Dewulf NLS, Santos V, Pereira LRL. Factors associated with potentially inappropriate medications use by the elderly according to Beers criteria 2003 and 2012. Int J Clin Pharm [Internet] 2014 [Accessed in 2020 Dec 10];36(2). Available in: https://doi.org/10.1007/s1 1096-013-9880-y

31. Oliveira MVP, Buarque DC. Polypharmacy and the use of potentially inappropriate medications among aged inpatients. Geriatr Gerontol Aging. 2018;12(1):38-44. https://doi.org/10.5327/Z2447211520181800001

32. Assis DL, Chagas VO, Valente M, Gorzoni ML. Polypharmacy and the use of inappropriate medications in institutionalized elderly: lessons still not learned. Geriatr Gerontol Aging. 2016;10(3):126-31. https://doi.org/10.5327/Z2447-211520161600020

33. Oliveira HSB, Corradi MLG. Aspectos farmacológicos do idoso: uma revisão integrativa de literatura. Rev Med (São Paulo) [Internet] 2018 [Accessed in 2020 Dec 10];97(2). Available in: https://doi. org/10.11606/issn.1679-9836.v97i2p165-176

34. Maio V, Jutkowitz E, Herrera K, Abouzaid S, Negri G, Del Canale S. Appropriate medication prescribing in elderly patients: how knowledgeable are primary care physicians? A survey study in Parma, Italy. J Clin Pharm Ther [Internet] 2011 [Accessed in 2020 Aug 20];36(4). Available in: https://onlinelibrary.wiley.com/action/ showCitFormats?doi=10.1111\%2Fj.1365-2710.2010.01195.x. https://doi.org/10.1111/j.1365-2710.2010.01195.x

35. Garcia TS. Medicamentos potencialmente inapropriados para idosos em uma Unidade Básica de Saúde de Ponto Alegre [dissertação]. Porto Alegre: Universidade Federal do Rio Grande do Sul; 2019.

36. Ramaswamy R, Maio V, Diamond JJ, Talati AR, Hartmann CW, Arenson $C$, et al. Potentially inappropriate prescribing in elderly: assessing doctor knowledge, confidence and barriers. J Eval Clin Pract [Internet] 2011 [Accessed in 2020 Jun 2];17(6). Available in: https://pubmed. ncbi.nlm.nih.gov/20630004/. https://doi.org/10.1111/j.13652753.2010.01494.x 